\title{
Antioxidant and colorectal anticancer potential of camel whey immunoglobulins
}

\section{Lubna Abdallah}

An-Najah National University. Faculty of Science. Department of Biology \& Biotechnology. Nablus. Palestine. Email: alubna@najah.edu.

\begin{abstract}
Camel whey considered as a potent source for many different biologically active proteins. According to that, this study was aimed to find out the antioxidant and anticancer activity of the prepared camel whey immunoglobulins. The in vitro effect of the prepared whey immunoglobulins concentrations on colon cells morphology and growth was investigated by tissue culture technique. Results showed that camel whey immunoglobulins reduced colon cell viability. Moreover, the obtained results revealed that these immunoglobulins had high antioxidant activity. In conclusion, this research support the scientific evidence of camel whey proteins beneficial effects in disease therapy.
\end{abstract}

Keywords: Camel whey; Immunoglobulins; Anticancer; Antioxidant.

Received

January 19, 2021

Accepted

April 28, 2021

Released

April 30, 2021

Full Text Article

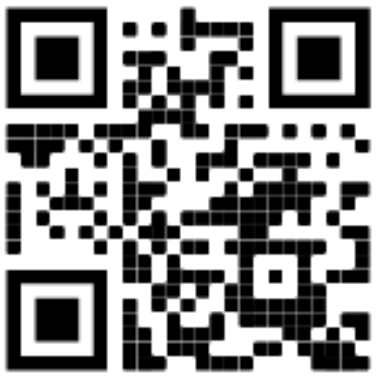

ORCID

(1) $0000-0001-7656-2673$

Lubna Abdallah

\section{Introduction}

Natural products considered to be one of the numerous sources of therapeutic agents. Among them, camel whey which acts as a nutritional supplement that is a good source of amino acids and biologically active proteins (Badr et al., 2017). Moreover, there is a growing evidence that camel whey proteins possess therapeutic properties in different pathological conditions. This is clearly noticed through the clinical trials using camel whey protein supplementation. These trials provided the immuno-modulator, antioxidant, antiinflammatory, antidiabetic, anti-thermal and antihypertensive activities (Low et al., 2003; Smith and Vane, 2003; Sanz Fernandez et al., 2014; Ajarem et al., 2015). Furthermore, studies showed that camel whey proteins supplementation maintain a high concentration of cellular antioxidants and boost immune defenses that promote carcinogen

ISSN 2358-2731/BJBS-2021-0001/2021/8/18/2/5

Braz. J. Biol. Sci.

http://revista.rebibio.net 
detoxification (Badr et al., 2017). In addition to that, camel whey protein display antibacterial, antiviral, iron binding, activities (El Sayed et al., 1992).

As oxidative stress appears to play an important role in many human diseases, there is a significant need for natural antioxidants. Camel whey proteins supposed to be one of those natural products that may play a central role as antioxidants in immunomodulation (Ebaid et al., 2012). However, all previous studies reported the antioxidant effects of whole milk, fermented milk, total protein hydrolysate and specific protein such as lactoferrin (Al-Ayadhi and Elamin, 2013; Habib et al., 2013; Zhu et al., 2016; Al-Shamsi et al., 2018; Ayyash et al., 2018). Otherwise, there is little information available in the literature about the antioxidant action of camel whey immunoglobulins. Consequently, this study was exploring the antioxidant activity of the these unique immunoglobulins.

\section{Materials and methods}

\section{Whey immunoglobulins preparation}

Milk samples were collected by a veterinary specialist from one female camel (Jenin, West Bank). For whey immunoglobulins preparation, the casein was precipitated from the pooled skimmed milk samples by milk renneting with commercially available rennin to obtain good crude contraction (Brussow et al., 1987). The coagulated milk was heated up to $56^{\circ} \mathrm{C}$ for $10 \mathrm{~min}$. Then, casein was separated from lacto serum by filtration. For final clarification, the lacto serum was centrifuged for $30 \mathrm{~min}$ at $10,000 \mathrm{rpm}$ at $4{ }^{\circ} \mathrm{C}$. After that, the obtained supernatant was filtered using a millipore filter $(0.45 \mu \mathrm{m})$. Then, the filtered supernatant was lyophilized to get powder of whey immunoglobulins pool. Total protein quantitation of the camel whey sample was determined by Biuret colorimetric assay (Gornall et al., 1949).

\section{In vitro morphological study}

The human colorectal cancer cell line was obtained from the American Type Culture Collection (ATCC, HCT116 number: CCL-247, from human the epithelial tissue of the colon). For a microscopic screening experiment, the cells were seeded into 12-well plates in $900 \mu \mathrm{L}$ of RPMI medium (Biological Industries, USA) containing 5\% FBS, at plating density of $\left(2 \times 10^{4}\right.$ cells/well). Whey immunoglobulins were solubilized in $0.2 \mathrm{M}$ phosphate buffer $(\mathrm{pH}=7)$. Then, $100 \mu \mathrm{L}$ of various concentrations $(1,2.5,5,7.5$, and $10 \mathrm{mg} / \mathrm{mL}$ ) was added in duplicates to the prepared 12 -well plates and incubated at $37{ }^{\circ} \mathrm{C}$, $5 \% \mathrm{CO}_{2}, 95 \%$ air and $100 \%$ relative humidity for $24 \mathrm{~h}$. To observe the morphological changes of the cells an inverted microscope was used (Labomed, USA).

\section{Antioxidant assay}

2,2-diphenyl-1-picryl-hydrazyl-hydrate (DPPH) free radical assay was carried out in a 96-well microplate (Jayanthi and Lalitha, 2012). In summary, $100 \mu \mathrm{L}$ of various concentrations of whey immunoglobulins in methanol $(0.5-0.01 \mathrm{mg} / \mathrm{mL})$ were added to $100 \mu \mathrm{L}$ of $0.01 \%$ methanolic DPPH solution. The plate was incubated for 30 min in the dark at room temperature and the absorbance was recorded at $540 \mathrm{~nm}$ using a micro plate reader (Labtech, UK). Ascorbic acid at different concentrations (0.5-0.01 mg/mL) was used as standard.

The DPPH radical scavenging activity (\%) was calculated as follows:

$$
\text { DPPH scavenging activity }(\%)=[(\text { A control }- \text { A sample }) / \text { A control }] \times 100
$$

Where was the absorbance of control (DPPH + Methanol without sample) and was the absorbance of sample (DPPH + Sample (whey/standard)). 


\section{Results and discussion}

Results showed that camel whey immunoglobulins reduced the viability of colon cells in a concentration dependent manner specially at $10 \mathrm{mg} / \mathrm{mL}$ (Figure 1). The obtained results revealed the cytotoxic potential of camel whey immunoglobulins as the microscopic examination performed after $24 \mathrm{~h}$. In this regards, most studies rely on the bovine whey protein on cancer. However, some studies showed the in vivo anticancer activity of camel milk and its constituents on colon cancer. For example, high concentration of camel milk lactoferrin induced growth arrest in colon cancer cells (Habib et al., 2013).

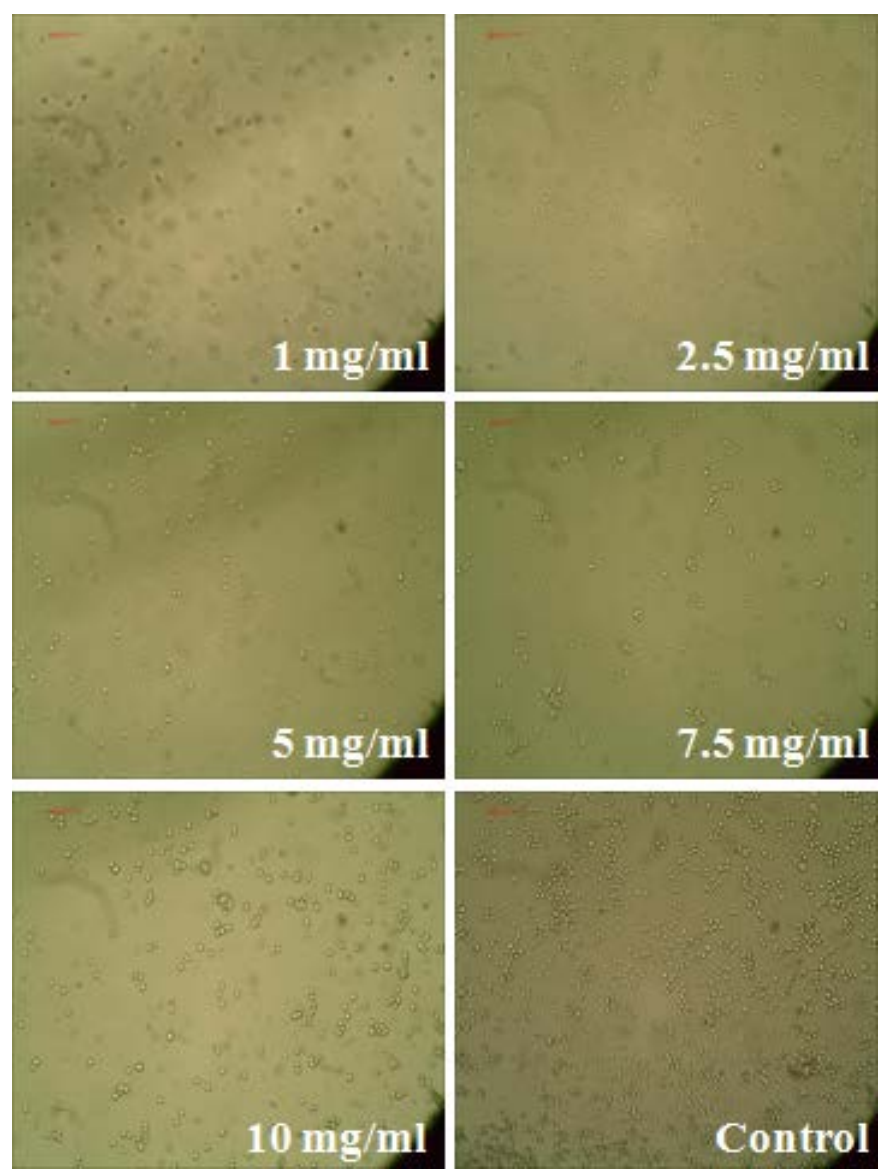

Figure 1. In vitro effect of camel whey immunoglobulins on colon cells at different concentrations $(\mathrm{mg} / \mathrm{mL})$.

Additionally, a study in an animal model of colon induced carcinoma revealed that whey protein decreased tumor burden and camel whey fed animals exhibited zero percentage of mortality (Papenburg et al., 1999). Also, researchers studied the effect of dietary supplementation with camel whey proteins on the chemically induced colon tumors. They found that the long-term consumption of camel whey proteins reduced the risk of colon cancer (Hakkak et al., 2001). 
Regarding the obtained results, the in vitro impact of camel whey immunoglobulins on the colorectal cancer cell line support the previous recorded experiments. Camel antibodies paid an attention to researchers in cancer therapy targeting and diagnosis. The main feature of these unique immunoglobulin types which are also called heavy chain antibodies is the absence of the light chains that are normally present in the conventional antibodies (Evers et al., 2008). Moreover, their small size provides them the ability to penetrate different tissues that cannot be reached by other antibodies (Cortez-Retamozo et al., 2002). In addition to that, these antibodies have the ability to recognize epitopes which are less antigenic for conventional ones (Lauwereys et al., 1998).

The antioxidant assay that is routinely employed in laboratories for the determination of the free radical scavenging potential of natural products is DPPH free radical scavenging assay. In this experiment, the obtained results revealed that camel whey immunoglobulins had high antioxidant activity (Figure 2). The increase in DPPH radical scavenging activity of camel whey immunoglobulins was in agreement with results obtained by some studies concerning the bioactive peptides obtained from enzymatic hydrolysis of camel milk and whey (Badr et al., 2017, Ibrahim et al., 2018; Abd El Rahim, 2020). In this aspect, Abd EL Rahim (2020) proved that the antioxidant properties of camel milk bioactive peptides are attributed to their composition, structure and hydrophobicity as well as position of amino acid residue, and the molecular weight.

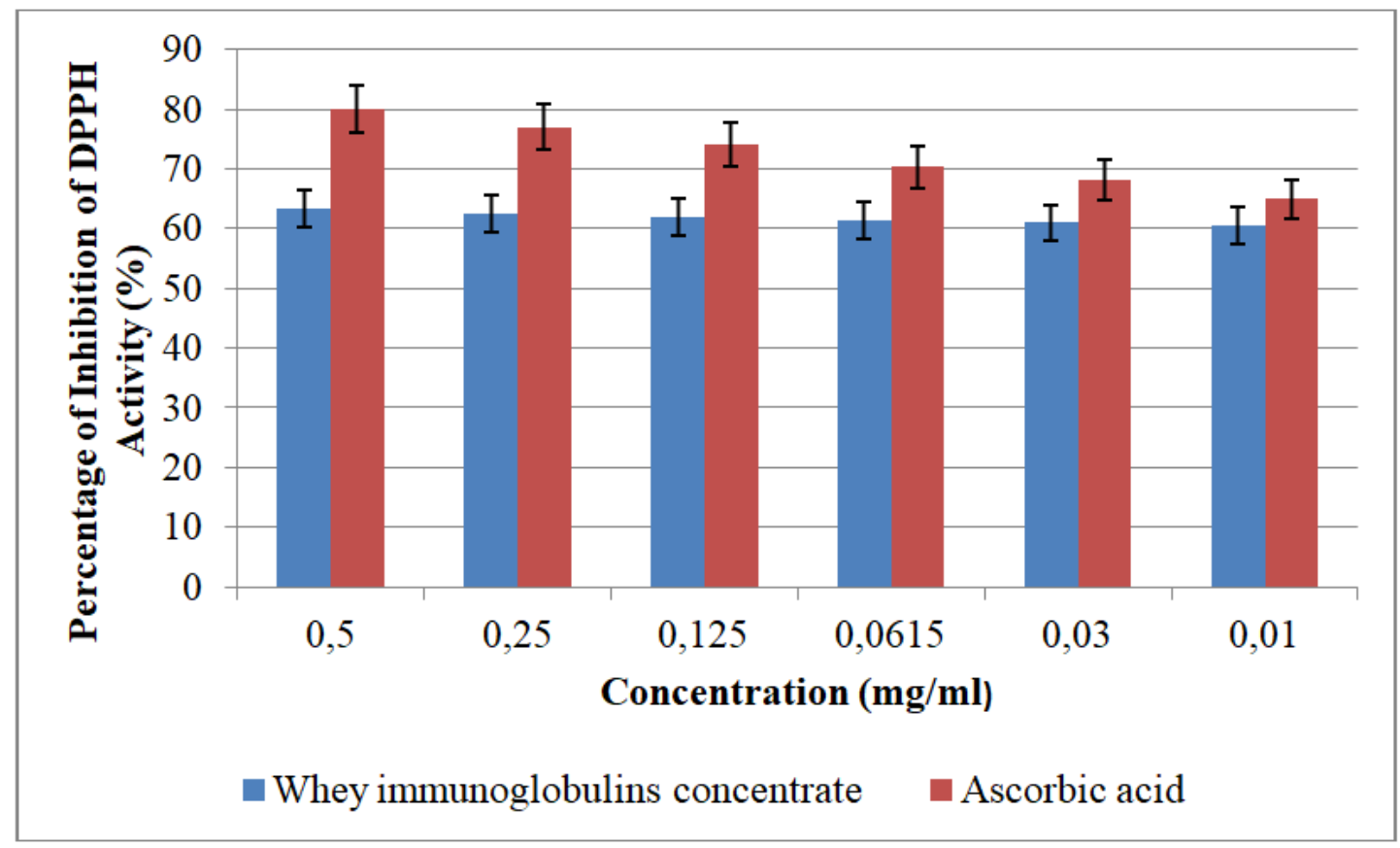

Figure 2. Percentage of inhibition of DPPH activity by whey immunoglobulins different concentration $(\mathrm{mg} / \mathrm{mL})$. 


\section{Conclusion}

It is interesting to note that camel whey immunoglobulins showed pronounced anticancer and antioxidant activities. So, the positive results presented in this research highlight the necessity of further in vivo experiments to figure out the exact mechanism of action against colorectal cancer. This research confirms the folkloric anticipation of camel whey as a therapeutic agent.

\section{Acknowledgment}

I would like to thanks Biology and Biotechnology Department at An-Najah National University for allowing me to access their facilities.

\section{Conflicts of interest}

The authors declare that they have no conflicts of interest.

\section{References}

Abd El Rahim, A. M. Antioxidant and antimicrobial activities of enzymatic hydrolysates of camel's milk whey protein and casein. Journal of Food Dairy Sciences, v. 11, no. 2, p. 45-50, 2020. https://doi.org/10.21608/jfds.2020.78877

Ajarem, J.; Allam, A. A.; Ebaid, H.; Maodaa, S. N.; AL-Sobeai, S. M.; Rady, A. M.; Metwalli, A.; Altoom, N. G.; Ibrahim, K. E.; Sabri, M. I. Neurochemical, structural and neurobehavioral evidence of neuronal protection by whey proteins in diabetic albino mice. Behavioral and Brain Functions, v. 11, 2015. https://doi.org/10.1186/s12993-015-0053-0

Al-Ayadhi, L. Y.; Elamin, N. E. Camel milk as a potential therapy as an antioxidant in autism spectrum disorder (ASD). Evidence-Based Complementary and Alternative Medicine, v. 2013, Article ID 602834, 2013. https://doi.org/10.1155/2013/602834

Al-Shamsi, K. A.; Mudgil, P.; Hassan, H. M.; Maqsood, S. Camel milk protein hydrolysates with improved technofunctional properties and enhanced antioxidant potential in in vitro and in food model systems. Journal of Dairy Science, v. 101, no. 1, p. 47-60, 2018. https://doi.org/10.3168/jds.2017-13194

Ayyash, M.; Al-Dhaheri, A. S.; Al Mahadin, S.; Kizhakkayil, J.; Abushelaibi, A. In vitro investigation of anticancer, antihypertensive, antidiabetic, and antioxidant activities of camel milk fermented with camel milk probiotic: A comparative study with fermented bovine milk. Journal of Dairy Science, v. 101, no. 2, p.900-911, 2018. https://doi.org/10.3168/jds.2017-13400

Badr, G.; Ramadan, N. K.; Sayed, L. H.; Badr, B. M.; Omar, H. M.; Selamoglu, Z. Why whey? Camel whey protein as a new dietary approach to the management of free radicals and for the treatment of different health disorders. Iranian Journal of Basic Medical Sciences, v. 20, no. 4, p. 338-349, 2017. https://doi.org/10.22038/IJBMS.2017.8573

Brussow, H.; Hilpert, H.; Walther, I.; Siidoti, J.; Mietens, C.; Bachmann, P. Bovine milk immunoglobulins for passive immunity to infantile rotavirus gastroenteritis. Journal of Clinical Microbiology, v. 25, p. 982-986, 1987. https://doi.org/10.1128/jcm.25.6.982986.1987 
Cortez-Retamozo, V.; Lauwereys, M.; Hassanzadeh, G.; Gobert, M.; Conrath, K.; Muyldermans, S.; De Baetselier, P.; Revets, H. Efficient tumor targeting by single-domain antibody fragments of camels. International Journal of Cancer, v. 98, no. 3, p. 456-462, 2002. https://doi.org/10.1002/ijc.10212

Ebaid, H.; Badr, G.; Metwalli, A. Immunoenhancing property of dietary un-denatured whey protein derived from three camel breeds in mice. Biologia, v. 67, p. 425-433, 2012. https://doi.org/10.2478/s11756-012-0014-0

El Sayed, I.; Ruppanner, R.; Ismail, A.; Champagne, C. P.; Assaf, R. Antibacterial and antiviral activity of camel milk protective proteins. Journal of Dairy Science, v. 59, p. 169-175, 1992. https://doi.org/10.1017/s0022029900030417

Evers, J. M.; Haverkamp, R. G.; Holroyd, S. E.; Jameson, G. B.; Mackenzie, D. D. S.; McCarthy, 0 . J. Heterogeneity of milk fat globule membrane structure and composition as observed using fluorescence microscopy techniques. International Dairy Journal, v. 18, p. 1081-1089, 2008. https://doi.org/10.1016/j.idairyj.2008.06.001

Gornall, A. G.; Bardawill, C. J.; David, M. M. Determination of serum proteins by means of the biuret reaction. Journal of Biological Chemistry, v. 177, no. 2, p. 751-766, 1949. https://doi.org/10.1016/S0021-9258(18)57021-6

Habib, H. M.; Ibrahim, W. H.; Schneider-Stock, R.; Hassan, H. M. Camel milk lactoferrin reduces the proliferation of colorectal cancer cells and exerts antioxidant and DNA damage inhibitory activities. Food Chemistry, v.141, p.148-152, 2013. https://doi.org/10.1016/j.foodchem.2013.03.039

Hakkak, R.; Korourian, S.; Ronis, M. J.; Johnston, J. M.; Badger, T. M. Dietary whey protein protects against azoxymethane-induced colon tumors in male rats. Cancer Epidemiology, Biomarkers \& Prevention, v. 10, no. 5, p. 555-558, 2001.

Ibrahim, H. R.; Isono, H.; Miyata, T. Potential antioxidant bioactive peptides from camel milk proteins. Animal Nutrition, v. 4, no. 3, p. 273-280, 2018. https://doi.org/10.1016/j.aninu.2018.05.004

Jayanthi, P.; Lalitha, P. DPPH scavenging assay of the solvent extracts and fractionates of Eichhornia crassipes (Mart.) Solms. Journal of Pharmacy Research, v. 5, no. 2, p. 946-948, 2012.

Lauwereys, M.; Ghahroudi, A.; Desmyter, A. Potent enzyme inhibitors derived from dromedary heavy-chain antibodies. The EMBO Journal, v. 17, p. 3512-3120, 1998. https://doi.org/10.1093/emboj/17.13.3512

Low, P. P. L.; Rutherford, K. J.; Gill, H. S.; Cross, M. L. Effect of dietary whey protein concentrate on primary and secondary antibody responses in immunized BALB/CMice. International Immunopharmacology, v. 3, no. 3, p.393-401, 2003. https://doi.org/10.1016/s1567-5769(02)00297-7

Papenburg, R.; Bounous, G.; Fleiszer, D.; Gold, P. Dietary milk proteins inhibit the development of dimethylhydrazine-induced malignancy. Tumour Biology, v. 11, p. 129-136, 1990. https://doi.org/10.1159/000217647

Sanz Fernandez, M. V.; Pearce, S. C.; Mani, V.; Gabler, N. K.; Metzger, L.; Patience, J. F.; Rhoads, R. P.; Baumgard, L. H. Effects of dairy products on intestinal integrity in heatstressed pigs. Temperature, v. 1, no. 2, p.128-134, 2014. https://doi.org/10.4161/temp.29561

Smith, C. G.; Vane, J. R. The discovery of Captopril. FASEB Journal, v. 17, p. 788-789, 2003. https://doi.org/10.1096/fj.03-0093life 
Zhu, W.-W.; Kong, G.-Q.; Ma, M.-M.; Li, Y.; Huang, X.; Wang, L.-P.; Peng, Z.-Y.; Zhang, X.-H.; Liu, X.-Y.; Wang, X.-Z. Camel milk ameliorates inflammatory responses and oxidative stress and downregulates mitogen-activated protein kinase signaling pathways in lipopolysaccharide-induced acute respiratory distress syndrome in rats. International Dairy Journal, v. 99, no. 1, p. 53-56, 2016. https://doi.org/10.3168/jds.2015-10005 